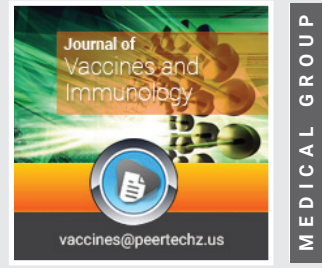

\section{A Commentary: The pandemic is calling for effective personal protection through innate immunological boosting}

\section{Chung-Lap Ben Chan', Chun-kwok Wong ${ }^{1,2}$ and Ping-chung Leung ${ }^{1,2 *}$}

${ }^{1}$ Institute of Chinese Medicine, The Chinese University of Hong Kong, Hong Kong

${ }^{2}$ State Key Laboratory of Research on Bioactivities and Clinical Applications of Medicinal Plants, The Chinese University of Hong Kong, Hong Kong
Received: 07 May, 2021

Accepted: 20 May, 2021

Published: 21 May, 2021

*Corresponding author: Ping-chung Leung, Hon DSocSc, DSc, HKAM, FHKCOS, MS, FRACS, FRCS (Edin), MB BS, Professor, State Key Laboratory of Research on Bioactivities and Clinical Applications of Medicinal Plants, The Chinese University of Hong Kong, Hong Kong, Tel: 85222528868; Fax: 26325441; E-mail: pingcleung@cuhk.edu.hk

\section{ORCID: https://orcid.org/0000-0002-0195-4688}

Keywords: Pandemic; Vitamin D; Immunoceuticals; Glycans innate immunity, "Trained immunity", "Immunological booster"

https://www.peertechzpublications.com

\section{Check for updates}

\begin{abstract}
It is logical to rely on effective vaccinations to overcome the pandemic as well as future up-coming epidemics. When the scale of involvement and the speed of spread are unusually wide and extensive, as is happening in the current Pandemic, vaccination cannot effectively satisfy the expectations.

Innate Immunity of the individual determines whether he or she is more resistant to infection, or on the contrary, more susceptible. A strong background of innate immunological defense ability allows the individual to resist infection and, even if infected will be able to maintain a mild course.

Recent studies have indicated that Innate Immunity could be "trained" to arrive at a more effective and more sustained ability to resist incoming adverse organisms: though short of specificity like vaccination, yet could provide a general combatting coverage, from the stage of early organism entry to the subsequent fight for elimination. Research has identified that micro-nutrients in food stuffs and special lipo- or glyco-proteins could provide enhancements in the perfect maintenance of the Immunological System to provide an ideal ground for "trained immunity" development.
\end{abstract}

Since Vitamin D has long been revealed being protective against respiratory infections via rather sophisticated pathways, it is suggested that it could be combined with other micro nutrients like $\beta$ glycan to form an effective Innate Immunity booster in support of specific vaccination.

\section{Introduction}

Since the third week of April 2021, India has been experiencing the most disastrous attack of the COVID-19 pandemic. The daily over 300,000 infection victims and over 3,000 mortalities are shocking the whole world.

The apparent total loss of control has been attributed to complicated issues related to virological science, public health management and social inequalities [1]. On the scientific area, the COVID-19 affecting India has been discovered to have undergone double or triple variant conversions resulting in more virulence and more rapid speed of spread. The sudden exacerbation of the Pandemic in India happened after the relaxation of the public health restriction measures: avoid gatherings, isolations, distancings, putting on masks etc. For some reasons, although India has been a great manufacturing source of vaccine production, nevertheless only about $2 \%$ of its population has been vaccinated. On the social inequality side, poverty in some areas could have been affecting hospitalization and normal clinical care, which sadly manifested as oxygen deprivation and other shortages.

The desperate situation might also indicate that some individuals might be more vulnerable than the average fellow citizens. Within the pandemic area, some individuals could be more resistant whereas some others could be more vulnerable because of their inferior innate defense ability. 
We used to identify special geographic areas in the world as being enthusiastic in the consumption of traditional nutritive supplements like the use of medicinal herbs, together with popular practices of special exercises. These regions should command better chances of protection against invading infections. With India's Ayurvedic medicine and Yoga practice, it should be in a favourable position. Indeed, when the 1918 influenza pandemic attacked the whole world, reports from China, another country fervently using traditional herbal medicine and special exercise like Tai Chi had apparently suffered less, manifested as fewer people infected and lower mortality [2].

\section{Traditional indian medicine and covid-19 pandemic}

There is the Ministry of AYUSH in the Indian government which is responsible for the job of promoting Traditional Indian Medicine. AYUSH stands for the five popular clinical traditions: Ayurveda, Yoga, Unani, Sidda and Homeopathy. The Indian Government in May 2020, has suggested measures that included the use of a formula consisting of Ginger, Curcumin, Cloves, Honey, Fennel, Cumin etc, called "Kadha" as an immunity booster [3]. Pharmacological and nonpharmacological instruction are advocated in Ayurveda for infection control [4]. Some Ayurvedic herbal preparations containing garlic, turmeric, carom and ajain have been used as oral disinfectant against COVID-19. Research has started on the use of Ayurvedic medicine for the pandemic [5]. Specific antiflu preparations using Arsenicum album and Bryonia have also been in active use and popular $[6,7]$.

Combined use of hydroxychloroquine and homeopathic medicine is widely practiced in Pune area, Indian, in the hospitals and more importantly, the combination has been given to over 2,000 people under quarantine. Gujrat government has issued guidelines on the use of Ayurvedic medicine as immune boosters [8]. The government of Kerala interlinked the framework of Traditional Indian Medicine with the public health administrative system to overcome the pandemic. The refined directives include the use of "Sukhayusham" for the elderlies; "Swasthyam" for the under 60"s; as well as using the Ayur Raksha Clinic to help the recovering patients [10]. For the symptom-free isolated people a number of specific preventive herbal formulae were successfully given [11-13].

Dr. Abhiskek Shanker and experts from Delhi, India, have reported in detail the current situation of Traditional Indian Medicine being used for the prevention and treatment of COVID-19 in India [14]. The active practice on Traditional Indian Medicine for prevention and treatment resembles very much what is happening in China today since the out-break in December 2019. Experts in China did very much related the popular use of Chinese herbal medicine to a better prevention and control of the pandemic $[15,16]$.

\section{Is there a role for herbal medicine to be used for perso- nal defense?}

In spite of the rather energetic support over the use of Ayurveda Medicine in India, the alarming spread of the COVID-19 infection has not been prevented. One might argue that social distancing and vaccinations are far more important and specific for prevention, and that when aggressive mutations occur, little can be done.

On the other hand, we have to agree that in spite of the aggressiveness and extensive coverage of the infection, some (or a lot) still manage to resist the infection and defend themselves. The personal level of protection with or without special vaccination cannot be ignored.

Looking around the world, the less developed countries and regions are relying significantly on herbal medicine.

Cuba among the Caribians is unique. Homeopathic medicine 'Prevengho-VIR' is used in Cuba for COVID-19 patients as preventive agent [18]. Large-scale homeoprophylaxis has been going on since 2020 and the low infection rate has been very impressive $[19,20]$.

Many African countries widely use traditional herbals against various infections [21,22]. Earlier in 2020 Madagascar widely advocated herbal "COVID-ORGANICS" (Ayurveda "Rajoelina") for COVID-19 prevention and treatment [22].

In the Asian counties and regions like Korea, Japan, China, Taiwan, Singapore and Malaysia, Tradition Herbal Medicine is also widely practiced, which may partially explain the relatively better controlled situations in the Pandemic, attributed very much to personal protection practices.

\section{A general framework for a wider preventive strategy}

The lesions we might have learned from South Asia include: that a new infection could behave extremely unexpectedly, so that the causative agent freely changes; public health measures might not be perfect and might not last; citizens might not conform to regulations; vaccines might not be available and if available, might not be adequately distributed. Under normal circumstances, those well-nourished and regularly exercising, might be taking supportive health supplements, like the South Asians, should be more capable to defend themselves against invading organisms; yet in an epidemic or pandemic, some of the less prepared still succumb.

Public Health measures are crucial and decisive in a pandemic. The value of the restrictions is best felt among those already well prepared with sufficient innate protections against the infection, compared with those not prepared. To achieve this the individual needs to maintain the perfect integrity of his/her Immune Defense System, which might require special up-boosting in time of need. What are the requirements? Nutrition is the determinant factor for the maintenance of general homeostasis and immune function. Special nutrients particularly Vitamin D are essential components to act as a booster [23,24]. Some food substances like glycoproteins and lipoproteins in the course of immunological research studies have been identified as being supportive in the promotion of innate immunological defense. Typical examples have been found in selective medicinal herbs commonly used in Traditional Chinese Medicine and Ayurveda Medicine [25-27]. 
The link between respiratory infections and Vitamin D has long been found [28]. The double roles of vitamin D include firstly, induction of the production of antiviral peptides such as cathelicidin in the respiratory epithelium which strengthens mucosal defense [29]. Secondly, it reduces cytokine production by enhancing the innate immune system and suppressing the over-activation of the adaptive immune system secondary to viral load [30].

With regard to medicinal herbs containing nutrients expressing appropriate immune-boosting effects, there are plentiful scientific publications giving objective evaluations related to laboratory evidences and clinical value [31,32]. Indeed, the herbs have been widely used in the past epidemics that happened in China and India since ancient days. However, one has yet to find these immune boosters to be used together with special nutrients like Vitamin D. The combination could possibly be shown to have synergistic effects, thus creating an innovative innate immunological booster for the therapeutic training of the immune system [33,34].

\section{Conclusion}

Before the start of the Pandemic, Harvard scholars brought to the Medical Public an important message: that Vitamin D could be recommended for the prevention of respiratory tract infection. Clinical and public health data, together with results of laboratory research were considered sufficient for the advocation. On the practical observations of winter and spring time respiratory infections, Northern countries and districts which were deficient of sunlight, thus negatively affecting the natural production of Vitamin D, suffered more incidences [23].

Compelling evidences from in-vitro experiments demonstrated that Vitamin D could act as a potent stimulator of innate antimicrobial responses [35,36]. Analysis of macrophage function through ex-vivo studies showed that supplementation with a single oral dose of Vitamin D enhanced donor macrophage responses to Bacillus infection [37]. Other laboratory evidences include that Vitamin $\mathrm{D}$ modulates the inflammatory responses to infection, regulates the reninangiotensin system [38].

Vitamin D receptors are present in most tissues throughout the body. This fact sets the stage that Vitamin D is a very much wanted micro-nutritional component in the human body expected to get involved in a number of metabolic and homeostatic activities, from the widely known calcium metabolism to the less known immune-supportive and antiinfection areas. Deficiency is certainly harmful. Whether extrasupplements is beneficial is a logical assumption although more solid scientific proof is yet being awaited [24].

While Vitamin D should be considered an important nutrient with excellent innate mechanisms of support in normal tissues to promote its role in immunological defense, if at the same time, another supportive nutritional could be provided from outside, double enhancing effects could be expected.

In our discussion, we proposed medicinal herbs which contain unique polysaccharides widely known as $\beta$ glycans.
The glycan-containing medicinal plants include special mushrooms like the coriolus species and gonoderma species. A few other medicinal plant roots have likewise been discovered to contain special glycoproteins and or lipoproteins that have been shown to have immune-boosting effects [39]. The word "Immunoceuticals" has been conveniently used to describe this group of supplements.

Practitioners in Traditional Medicine, (both Indian and Chinese) own valuable experiences and expertise in the use of immunoceuticals, but their philosophy and choices differ significantly. Decades ago, and in traditional classics, their expectations concentrate on infection control and prevention [40]. In reason years much interests have been diverted to cancer control (41). More and more evidences are collected from research platforms on the mechanisms driving the immuneboosting effects of the selected herbal products.

Natea developed a new concept he called "trained immunity". He found that past vaccination of any kind or a current infection could affect monocytes/ macrophages to undergo a functional re-programming so that an enhanced defensive response against future invasion of unrelated organism can be displayed. Laboratory animal experiments of Candida albicans and other infections also demonstrated that the animals develop resistance against re-infection via the functional reprogramming of monocytes. Moreover, $\beta$ glycans enhanced the "trained immunity" effects $[42,43]$.

Vitamin D may protect against invading infections as an ever-ready sentinel which may require further strengthening. Immunoceuticals could selectively come in to reinforce the defense, providing additional and possibly synergistic effects [44].

This might be a suitable time, for the well-known aspects of the innate immunological defense be seriously studied and be included into the immediate future planning, against epidemics, which should not be confined to specific vaccine development but could include the therapeutic personal protection against aggressive infections, basing on innate immunity $[45,46]$.

\section{References}

1. Apple News (2021) What we know about India's Double Mutant COVID-19 Variant. Wall Street Journal. Link: https://on.wsj.com/2T72I1q

2. Cheng KF, Leung PC (2007) What happen in China during the 1918 influenza pandemic. Int J Infect Dis 11; 360-364. Link: https://bit.ly/3v409J9

3. Advisory for Corona virus from AYUSH Ministry. Link: https://bit.ly/2QFmf2M

4. Pandey DN (2019) Seven shields of ayurveda between health and diseases Annals Ayurvedic Med 8: 6-10. Link: https://bit.ly/3tZrNCB

5. Bhatwalkar SB, Shukla P, Srivastava RK, Mondal R, Anupam R (2019) Validation of environmental disinfection efficiency of traditional Ayurvedic fumigation practices. J Ayurveda Integr Med 10: 203-206. Link: https://bit.ly/3hFXaQ5

6. Mathie RT, Baitson ES, Frye J, Nayak C, Manchanda RK, et al. (2013) Homeopathic treatment of patients with infl uenzalike illness during the 2009 A/H1N1 infl uenza pandemic in India. Homeopathy 102: 187-192. Link: https://bit.ly/3whu8un 
7. Chakraborty P, Lamba C, Nayak D, John M, Sarkar D, et al. (2013) Effect of individualized homoeopathic treatment in influenza like illness: A multicenter, single blind, randomized, placebo controlled study. Indian J Res Homoeopathy 7: 22-30. Link: https://bit.ly/3wf49Ue

8. Khelkar PP (2020) Coronavirus: 18 nurses at Pune hospital test positive doctor treats staff with HCQ, homeopathy. Link: https://bit.ly/3fBuaX6

9. COVID-19 (nCorona) Virus Outbreak Control and Prevention State Cell Health \& Family Welfare Department Government of Kerala [cited 2020 May 11]. Link: https://bit.ly/2QAY6dF

10. Ayurveda will be used in the prevention and treatment-CM (2020) Link: https://bit.ly/3ytOwKv

11. Bisht D, Sharma Y, Mehra B (2009) A clinical study to evaluatethe efficacy of Pippali Rasayana in certain respiratory disorders. AYU An international Quarterly Journal Research Ayurveda 30: 337-341. Link: https://bit.ly/3fvmdmt

12. Makhija IK, Shreedhara CS, Ram HN (2013) Mast cell stabilization potential of Sitopaladi churna: An ayurvedic formulation. Pharmacognosy Res 5: 306-308. Link: https://bit.ly/2T7382o

13. Srikanth N, Singh A, Ota S, Sreedhar B, Galib, Dhiman KS (2019) Chemical characterization of an Ayurvedic herbo-mineral preparation-Mahalaxmivilas Rasa. J Ayurveda Integr Med 10: 262-268. Link: https://bit.ly/3yqfUsX

14. Shankar A, Dubey A, Saini D, Prakash Prasad C (2020) Role of Complementary and Alternative Medicine in Prevention and Treatment of COVID-19: An Overhyped Hope. Chin J Integr Med 26: 565-567. Link: https://bit.ly/3f1PAO4

15. Li Y, Liu X, Guo L, Li J, Zhong D, Zhang Y, et al. (2020) Traditional Chinese herbal medicine for treating novel coronavirus (COVID-19) pneumonia: protocol for a systematic review and meta-analysis. Systematic Rev 9: 75. Link: https://bit.ly/2T0gU6J

16. Cyranoski D (2020) China is promoting coronavirus treatments based on unproven traditional medicines: Nature news 2020 Link: https://go.nature. com/3woru5Q

17. Yang Y, Islam MS, Wang J, Li Y, Chen X (2020) Traditional Chinese medicine in the treatment of patients infected with 2019-New coronavirus (SARSCoV-2): a review and perspective. Int J Biological Sci 16: 1708-1717. Link https://bit.ly/33XSJYY

18. Yaffe H (2021) The world discovers Cuban Medical Internationalism. Cuba's welcome to a COVID-19-Stricken ship. Link: https://bit.ly/2ScdEVG

19. Lalvinay (2020) Socialized Health care and Medical internationalism: Cuba and the Coronavious. Dept of History. UCLA.

20. Evnesto M (2020) COVID-19: Cuban Medicine is helping to defeat the virus Link: https://bit.ly/2QAgQK9

21. Lobine D (2020) Do African herbal medicines hold hope for 2020. Link: Link: https://bit.ly/3f5cG6I

22. WHO Africa: WHO supports scientifi cally-proven traditional medicine 2020 . Link: https://bit.ly/3oCRfNd

23. Mc Greerey S, Morrison M (2017) Study confirms Vitamin D protects against cold and flu. Harvard Gazette.

24. Gruber-Bzura BM (2018) Vitamin D and Influenza-Prevention or Therapy? Int J Mol Sci 19: 2419. Link: https://bit.ly/3blLush

25. Chan B, Wong CK, Leung PC (2020) What can we do for the Personal Protection against the CoVID-19 Infection? Immuno-Boostering Specific Supplement could be the Answer. J Emerg Med Trauma Surg Care 2: 007. Link: https://bit.ly/3fouRWf

26. Ping-Chung L, Chung-Lap Ben C, Chun-Kwok W (2020) Clinical Use of Chinese Medicine in the Current COVID-19 Crisis and Related Research Planning. Clin Res Infect Dis 5: 1054
27. Leung PC, Panda D (2017) Ayurveda and Chinese Medicine Today: Joint Mission of the Two Asian Systems. Book: "From Ayurveda to Chinese Medicine", World Scientific Publishing Singapore 231-242. Link: https://bit.ly/3oxQK7a

28. Kaler J, Hussain A, Nasim S, Azim D, Ali S (2021) Optimising vitamin D levels in patients with COVID-19. Hong Kong Med J 27: 154-156. Link: https://bit.ly/3whol2v

29. Gombart AF, Borregaard N, Koeffler HP (2005) Human cathelicidin antimicrobial peptide (CAMP) gene is a direct target of the vitamin $\mathrm{D}$ receptor and is strongly up-regulated in myeloid cells by 1,25-dihydroxyvitamin D3. FASEB J 19: 1067-1077. Link: https://bit.ly/2S8GExp

30. Greiller CL, Martineau AR (2015) Modulation of the immune response to respiratory viruses by vitamin D. Nutrients 7: 4240-4270. Link: https://bit.ly/2RpOK4Z

31. Ragupathi G, Yeung KS, Leung PC, Cassileth B, Lee M, Lau CB, et al. (2008) Evaluation of widely consumed botanicals as immunological adjuvants. Vaccine 26: 4860-4865. Link: https://bit.ly/33XudXU

32. Hong F, Xiao W, Ragupathi G, Lau CB, Leung PC, et al. (2011) The known immunologically active components of Astragalus account for only a small proportion of the immunological adjuvant activity when combined with conjugate vaccines. Planta Med 77: 817-824. Link: https://bit.ly/3bJbqUq

33. Fung KP, Leung PC, Tsui KW, Wan CC, Wong KB, et al. (2011) Immunomodulatory activities of the herbal formula Kwan Du Bu Fei Dang in healthy subjects: a randomised, double-blind, placebo-controlled study. Hong Kong Medical Journal 17: 41-43. Link: https://bit.ly/3hFi2qJ

34. Gombart AF, Pierre A, Maggini S (2020) Review of Micronutrients and the Immune System-Working in Harmony to Reduce the Risk of Infection Nutrients 12: 236. Link: https://bit.ly/3hEp4vQ

35. Hewison M (2011) Antibacterial effects of Vitamin D. Nat Rev Endocrinol 7: 337-345. Link: https://bit.ly/3fvRsxz

36. Holick MF (2009) Vitamin D status, measurement, interpretation, and clinica application. Ann Epideniol 19: 73-78. Link: https://bit.ly/3hH7CH1

37. Martineau AR, Wilkinson RJ, Wilkinson KA, Newton SM, Kampmann B, et al. (2007) A single dose of Vitamin D enhances immunity to mycobacteria. Am J Respir Crit Care Med 176: 208-213. Link: https://bit.ly/3hGlvEg

38. Manson J, Bassuk SS (2020) Eliminating Vitamin D deficiency during the COVID 19 pandemic?. Metabolism Clinical and Expt 112: 154322. Link: https://bit.ly/3v5suvH

39. Borchers AT, Stern JS, Hackman RM (1999) Mushrooms, tumours and immunity. Prooc Soc Exp Biol Med 221: 281-283. Link: https://bit.ly/3ozoQYD

40. Leung PC (2020) Epidemic Diseases and Chinese Medicine - From ancient to current time. J Trop Med Inf Disease 1. Link: https://bit.ly/3vhKsLH

41. Chihara G, Hamuro J, Maeda YY (1987) Antitumor and metastasis-inhibitory activities of lentinan as an immune modulator. Cancer Detect Prev Suppl 1 : 423-443. Link: https://bit.ly/3u4KEwi

42. Netea MG, Dominguez-Andres J, Barreiro LB, Chavakis T, Divangahi M, et al. (2020) Defining trained immunity and its role in health and disease. Nat Rev Immunol 20: 375-388. Link: https://bitly/3iH6A1.

43. Netea MG, Giamarellos-Bourboulis EJ, Domínguez-Andrés J, Curtis N, van Crevel $\mathrm{R}$, et al. (2020) Trained immunity: a tool for reducing susceptibility to, and the severity of SARS-COV-2 infection.Cell 181: 969-977. Link: http://bit.ly/2Hwfdbt

44. Poon P Mak, Wong CK, Fung KP, Fong CY, Wong EL, et al. (2006) Immunomodulatory Effects of a Traditional Chinese Medicine with Potential Antiviral Activity: A self-Control Study. Am J Chin Med 34: 13-21. Link: https://bit.ly/3yrVCiz

Citation: Ben Chan CL, Wong CK, Leung PC (2021) A Commentary: The pandemic is calling for effective personal protection through innate immunological boosting. J Vaccines Immunol 7(1): 009-013. DOI: https://dx.doi.org/10.17352/jvi.000039 
45. van der Meer JW, Joosten LA, Riksen N, Netea MG (2015) Trained immunity: A smart way to enhance innate immune defence. Mol Immunol 68: 40-44. Link: https://bit.ly/3ozNSGX
46. Chan BC, Leung PC, Cheng WKF, Lin Z, Yu ECL, et al. (2020) Going Along the Direction of Trained Immunity - a Herbal Supplement for the Prevention of Respiratory Infection. J Vaccines Immunol 6: 032-037. Link: https://bit.ly/3fC8fiN
Discover a bigger Impact and Visibility of your article publication with

\section{Peertechz Publications}

\section{Highlights}

* Signatory publisher of ORCID

* Signatory Publisher of DORA (San Francisco Declaration on Research Assessment)

- Articles archived in worlds' renowned service providers such as Portico, CNKI, AGRIS, TDNet, Base (Bielefeld University Library), CrossRef, Scilit, J-Gate etc.

* Journals indexed in ICMJE, SHERPA/ROMEO, Google Scholar etc.

* OAI-PMH (Open Archives Initiative Protocol for Metadata Harvesting)

* Dedicated Editorial Board for every journal

* Accurate and rapid peer-review process

* Increased citations of published articles through promotions

* Reduced timeline for article publication

Submit your articles and experience a new surge in publication services (https://www.peertechz.com/submission).

Peertechz journals wishes everlasting success in your every endeavours.

Copyright: @ 2021 Ben Chan CL, et al. This is an open-access article distributed under the terms of the Creative Commons Attribution License, which permits unrestricted use, distribution, and reproduction in any medium, provided the original author and source are credited. 